This is an electronic reprint of the original article. This reprint may differ from the original in pagination and typographic detail.

Author(s): Arentshorst, Hans

Title: $\quad$ Social Freedom in Contemporary Capitalism : a Reconstruction of Axel Honneth's Normative Approach to the Economy

Year: $\quad 2015$

Version:

Please cite the original version:

Arentshorst, H. (2015). Social Freedom in Contemporary Capitalism : a

Reconstruction of Axel Honneth's Normative Approach to the Economy. Studies in Social and Political Thought, 25, 132-151. https://doi.org/10.20919/sspt.25.2015.31

All material supplied via JYX is protected by copyright and other intellectual property rights, and duplication or sale of all or part of any of the repository collections is not permitted, except that material may be duplicated by you for your research use or educational purposes in electronic or print form. You must obtain permission for any other use. Electronic or print copies may not be offered, whether for sale or otherwise to anyone who is not an authorised user. 


\title{
7. Social Freedom in Contemporary Capitalism: A Reconstruction of Axel Honneth's Normative Approach to the Economy
}

\author{
by Hans Arentshorst
}

\section{Introduction}

One of the central concerns in the work of Axel Honneth has been to develop a normative, critical approach to the economy. This concern can be traced back to Honneth's $(1980 ; 1986 a)$ criticism of the social theory of Jürgen Habermas, which revolves around two related issues. First of all, Honneth is not convinced that Habermas's system-theoretical approach to the economy - which analyzes it as a norm-free sphere that can reproduce itself independently of the moral approval of its participants - can give an adequate account of social reproduction and social change in the economic sphere. Secondly, Honneth is worried that Habermas neglects the socioeconomic preconditions of the ideal of a deliberative democracy. Whereas the first issue is about the question of how to adequately describe the economy within the framework of a critical social theory, the second issue is concerned with the interrelationship between the social and the political dimensions of democracy.

In this paper I want to reconstruct Honneth's struggle to develop adequate answers to these two issues. I will first reconstruct Honneth's attempt to develop an approach that analyzes the economy as a sphere of recognition in which people struggle for respect and esteem ( $\$ 1)$; then I will look at Honneth's recent work in which he introduces the method of 'normative functionalism', and will show how this method is related to his attempt to develop a conception of a 'democratic Sittlichkeit' that stresses the importance of a just division of labor for generating the necessary motivation for people to participate in deliberative politics (\$2); and I will end with some critical remarks (\$3). In doing this, I hope not only to contribute to a better understanding of some of the central issues in Honneth's work, but also to show both the promises and problems of his work for analyzing and criticizing contemporary developments in the economy. 


\section{A Reconstruction of Honneth's Normative Approach to the Economy}

Honneth's attempt to develop a normative approach to the economy can be divided into two general projects. On the one hand, he has been trying throughout his philosophical career to develop an alternative to Habermas's system-theoretical approach to the economy. On the other hand, as the director of the Institüt fur Sozialforschung (Institute for social research), Honneth has initiated a research-project that studies the paradoxes of contemporary capitalism, whereby researchers from different disciplines try to analyze and criticize the recent change from a social-democratic to a neoliberal society.

To better understand how these two projects relate, it might be helpful to turn to a short essay by Honneth called 'Reconstructive social criticism with a genealogical proviso' in which he gives a short summary of the leftHegelian methodology of the so-called 'Frankfurt School'. As Honneth (2007a, 63) tells us, this methodology consists of three moments: a reconstructive moment, a constructive moment, and a genealogical moment. First of all, the normative ideals with which the Frankfurt School criticizes society are not to be imposed from the outside, but should already be at work in society, and therefore a reconstruction of the immanent normative ideals in society is required. However, not all ideals at work in society are emancipating, so in order to be able to decide which normative ideals and developments are emancipating and which are pathological, a constructive moment is needed, and in Honneth's understanding this means the construction of a context-transcending concept of rationality. Finally, because certain normative ideals that were initially emancipating can, in subtle ways, change their meaning and become pathological, a genealogical moment is needed that looks historically at the changing ways in which certain normative ideals are actually being understood and applied in society. ${ }^{1}$

With the help of this short exposition of the central features of the leftHegelian methodology, it is now easier to see how Honneth's two projects relate: in his philosophical work he has been struggling to develop a critical approach to the economy that is both immanent and rational, combining the reconstructive and constructive moments of the left-Hegelian methodology; and with the Institüt für Sozialforschung he has complemented this with a genealogical analysis, trying to understand how certain normative ideals in the economy that were initially emancipating have changed their meaning during the 'neoliberal revolution' and turned into pathological, disciplining ideals. In the following reconstruction, I will take these different moments of the left-Hegelian methodology as my guiding thread. 


\subsection{The Craftsman Ideal}

The problems related to the development of an approach to the economy that is both immanent and rational are clearly illustrated in an early essay by Honneth called 'Arbeit und instrumentales Handeln' ('Labor and instrumental action'). In this article, Honneth praises Habermas for having opened up new ways out of the Marxist paradigm of the first generation of Critical Theory by making the distinction between labor and interaction. The problematic connection made by Marx between work and emancipation is analytically separated by Habermas into two different types of action instrumental and communicative action - each with their own rational potential, thereby opening up the possibility of conceptualizing emancipation in intersubjective terms. ${ }^{2}$

Although Honneth welcomes Habermas's 'intersubjective turn', he objects to the fact that Habermas reduces moral-practical emancipation to the sphere of communicative action (i.e. the life-world), because this makes him blind to the moral-practical struggles of workers within the sphere of instrumental action. In order to bring these struggles into focus, Honneth tries in his article to rehabilitate the Marxist distinction between alienated and non-alienated work. After pointing to contemporary empirical studies that show how industrial workers are trying to re-appropriate their alienated working conditions, Honneth argues that this struggle for autonomous, nonalienated working-conditions - what he calls the craftsman ideal - is the immanent norm at work in the economy. ${ }^{3}$

However, Honneth soon realized that this craftsman ideal cannot be universalized and made into a legitimate rational principle. Because of the complex division of labor in contemporary capitalism, and because the jobs that are necessary for society's reproduction in our post-industrial service economy are of such a diverse nature, it seems impossible to structure them all on the same craftsman ideal. Therefore, Honneth moved away from analysing the conditions of the working activity itself towards the moral norms underlying the capitalist organisation of labor. ${ }^{4}$

\subsection{The Problem of Social Esteem}

Based on his reading of the philosophy of Hegel and the labor histories of Barrington Moore, E.P. Thomson, and Richard Sennett (Boltanski/Honneth 2009, 88; Honneth 1992, 267-269), Honneth became convinced that social conflicts - including those in the economy - should be understood, not as interest-based struggles, but as moral struggles for recognition. This idea, however, was absent in the dominant critical theories of Horkheimer, 
Adorno, Foucault, and Habermas. As Honneth $(1986,332)$ argued in The Critique of Power, the reason why these moral struggles have no place in these theories, is that they each make the mistake of a 'hypostatization of social spheres as systems,' which means that they present social spheres such as the economy as reproducing themselves independently of the moral consensus and approval of the subjects involved. Honneth therefore wanted to develop a critical social theory that stayed close to the everyday, firstperson experiences of individuals in order to give these normative social struggles a proper place, and to give a more convincing account of how society reproduces itself.

This resulted in The Struggle for Recognition where Honneth articulates a critical theory that revolves around the idea that individuals need different forms of recognition (love, respect and social esteem) for their healthy selfrealization. In developing his theory, Honneth again tried to fulfil the left-Hegelian criteria of immanence, by articulating an empirically grounded phenomenology of the forms of recognition (Honneth 1992, 150, 259), and of rationality, by developing a formal conception of ethical life (Sittlichkeit; Honneth 1992, Ch. 9). It is again the rational moment of the left-Hegelian method that causes Honneth the most difficulties.

Honneth argues that the aim of his theory of recognition is not just to provide an explanation of the causes of social conflicts and struggles, but also to place these struggles within a framework of moral progress in which they can be understood as different stages in a moral learning process. ${ }^{5}$ In order to provide normative criteria with which to evaluate which struggles for recognition are contributing to moral progress and which are undermining it, Honneth articulates a hypothetical end state of this moral development - which he calls a formal conception of ethical life - in which all the intersubjective preconditions of individual self-realization are in place.

One of the requirements of this formal conception of ethical life, Honneth argues, is that it should be compatible with modern ethical pluralism and modern autonomy, and therefore should not prescribe a specific idea of the good life. As Honneth realizes, this requirement becomes problematic when it comes to providing possibilities for social esteem. Following Hegel and Mead, Honneth $(1992,196)$ endorses the idea that individuals need social esteem of their specific traits and abilities to establish a positive self-relation. He further argues that individuals can only acquire this form of social esteem when they contribute to the collective goals and projects of society in which their traits and abilities can be of specific value. In this way, social esteem is dependent on the specific ethical horizon of a society, which determines its goals and projects and thus the value of certain traits and abilities. 
The challenge for Honneth is therefore to find an ethical framework for a post-traditional solidarity, in which people can be socially esteemed, but which is also 'thin' enough to be open to different individual life-goals. Honneth concludes that both Hegel and Mead failed to meet this challenge, and he admits that he does not have the answer either. He ends his book by saying that there is an unresolvable tension we have to live with: on the one hand social esteem is necessary for healthy human self-realization, but the shared ethical ideas needed for social esteem are themselves the object of constant social struggles and therefore cannot be settled by theoretical argument.

\subsection{From 'Thick' Solidarity to 'Thin' Achievement}

One of the reasons why the economy plays a minor role in The Struggle for Recognition is because Honneth still rejects here the proposal of Mead and Durkheim to see the modern division of labor as the basis of solidarity and social esteem within an ethically plural society. ${ }^{6}$ However, Honneth soon became convinced that the principle of achievement (Leistung) is 'thin' enough to provide individuals with social esteem without being dependent on shared ideas of the good life. By linking social esteem to the individual's contribution to the cooperative task of the material reproduction of society, Honneth thought he could largely avoid problems concerning ethical differences, thus moving from the 'thick' principle of solidarity to the 'thin' principle of achievement. ${ }^{7}$ In this way, he was now in a position to articulate a recognition-theoretical approach to the economy.

In Redistribution or Recognition? Honneth argues that the immanent norms at work in western capitalism have been the struggles for two forms of recognition: social esteem based on one's achievements in society, and respect based on equal rights. At the same time, Honneth presents two context-transcending principles with which to evaluate which struggles contribute to moral progress and which do not, namely the principles of individualization and social inclusion (Fraser/Honneth 2003, 218). This means that only those struggles for recognition that either recognize new aspects of the individual that were not recognized before, fostering the process of individualization, ${ }^{8}$ or that increase the number of people that are included in the recognition order of the economy, improving social inclusion, can be understood as moral progress.

On the basis of these criteria Honneth reconstructs the developments leading to the emergence of western capitalism as moral progress (Fraser/Honneth 2003, 219). These struggles started when the bourgeoisie rejected the status-based forms of recognition within hierarchical, aristocratic 
societies, and demanded that these traditional forms of recognition would on the one hand be democratized, by recognizing everyone as subjects of equal rights, thereby increasing the level of social inclusion; and on the other hand meritocratized, by recognizing one's achievements within society, which increased the level of individualization (Fraser/Honneth 2003, 166). Honneth is mainly interested in the two struggles that continue this initial process: either people struggle for a reinterpretation of the meritocratic achievement principle in order to overcome one-sided, ideological interpretations, ${ }^{9}$ or people struggle for social rights, demanding, in the name of equal recognition, a minimum of basic goods for everybody, independent of one's achievement. The result of these struggles was the welfare state, in which a small part of the goods of society are being distributed on the basis of equal social rights, and the remaining, larger part is divided according to the achievement principle (Fraser/Honneth 2003, 176-177). In this way there was a balance achieved between the two context-transcending principles of individualization and social inclusion.

\subsection{Neoliberal Pathologies}

In his work with the Institut für Sozialforschung (Honneth 2002; 2010b; 2013a) Honneth has tried to show that this emancipating development of capitalism has taken a pathological turn in our time - which brings us to the genealogical moment of the left-Hegelian methodology. Honneth argues that the new aspirations towards authenticity and self-realization prevalent since the 1960's have become entangled with neoliberal practices, which has resulted in the paradoxical development that these aspirations did not lead to a qualitative increase in freedom, but to an ideology of de-institutionalization (Honneth 2002, 146) whereby the social preconditions of individual freedom are de-institutionalized, which led to new kinds of social pathologies. Whereas social pathologies in overregulated societies, such as those of the 1950s and 60s, were usually the result of the disciplining and normalization of individuals to conform to socially prescribed roles, in our current deregulated societies it seems that a new disciplinary model has emerged in which permanent creative self-realization has become the new conformism. The constant social pressure to take initiative, to be flexible and to be creative - all in the name of market competitiveness - has become the new social coercion. This social demand of permanent creative self-realization combined with the idea that there are no limits to the power of individuals to shape their own lives - has resulted in an increase of depressive symptoms in society, with many people being uncertain about their identity, suffering from feelings of inner emptiness, and having a lack of self-confidence. ${ }^{10}$ 
Another way to describe this is that the struggles for respect and esteem have recently developed in such a way that they have undermined the processes of individualization and social inclusion. The central ideals associated with individualization, such as self-responsibility and selfrealization, have changed their meaning, which has made it more difficult for individuals to receive social esteem for their achievements, and at the same time more and more individuals are excluded altogether from the recognition-order of the economy. ${ }^{11}$ Whereas the welfare state represented a healthy balance between the processes of individualization and social inclusion, the neoliberal politics of deregulation and the ideology of deinstitutionalization have caused a pathological development, making it more and more difficult for people to receive respect and esteem in their economic lives.

\section{Democratic Sittlichkeit and Normative Functionalism}

In his more recent work, Honneth has introduced the methodological approach of 'normative functionalism' to critically analyze the economy, which is largely a continuation of his approach as discussed so far. However, before discussing this method, I will first try to put Honneth's approach to the economy in a broader context by looking at his attempt to connect the social and political dimensions of democracy by developing a conception of 'democratic Sittlichkeit.'

\subsection{A Just Division of Labor as a Precondition of a Revitalized Democracy}

A first attempt to articulate a conception of 'democratic Sittlichkeit' can be found in Honneth's article 'Democracy as reflexive cooperation: John Dewey and the theory of democracy today.' In this article, Honneth discusses the criticism made by the two dominant radical-democratic positions - namely the republicanism of Hannah Arendt and the proceduralism of Jürgen Habermas - against a purely liberal understanding of politics. The problem with the liberal understanding of politics, these two positions argue, is its negative, individualistic understanding of freedom, in which individuals are understood as being autonomous, independent of any social interaction. This legitimates a reductive understanding of political participation whereby individuals once in a while evaluate whether the state succeeds in protecting their individual liberties. Against this individualistic understanding of freedom, the republican and procedural positions defend a communicative understanding of freedom, where autonomy can only be realized by participating in the intersubjective will-formation in the public sphere. 
Honneth argues that both approaches are flawed. He thinks that the republicanism of Arendt is too ethical: it presupposes political virtues of citizens and that political participation should be the central goal in their lives, which is irreconcilable with ethical pluralism in modern societies. The problem with the proceduralism of Habermas is that it is too formal and onesidedly concerned with only the political aspect of democracy, which hinders an understanding of the way in which political deliberation is dependent on social-economic equality.

In Dewey's conception of democracy, Honneth thinks he has found a fruitful alternative to both an overly ethical republicanism and an empty proceduralism. Although Dewey also criticizes the liberal, individualistic conception of freedom and endorses a communicative idea of freedom, he bases this not on a model of intersubjective reason, but on a model of social cooperation. Dewey understands individual freedom as the self-realization of an individual within a cooperative division of labor, and he understands democratic deliberation as the problem-solving, reflexive moment of such a cooperative society. This idea of democracy presupposes that the division of labor in society is organized in a fair and just manner so that every member can understand himself as part of a cooperative whole. Only when individuals can understand their work as a meaningful contribution to a cooperative society can they see the value of democratic deliberation as being the best instrument to rationally solve collective problems. In this way, Honneth $(2000,286)$ argues, Dewey connects the two ideals of democratic community and rational deliberation, which in the discussions between republicans and proceduralists have become separated. In Dewey's work we can find the connection of democracy as a political and social ideal (ibid., 309). ${ }^{12}$

Towards the end of Freedom's Right, where Honneth (2011, 612ff) discusses the preconditions of a healthy political culture, he again makes the Deweyan claim that the motivation of individuals to participate in democratic will-formation is dependent on the quality of the social relations in the two spheres of the economy and the family, and on the possibility to understand these spheres as cooperative spheres of social freedom. ${ }^{13}$ Considering the fact that for Dewey and Honneth the revitalization of deliberative democracy presupposes a 'democratic Sittlichkeit' that is not anchored in political virtues, but in the consciousness of social cooperation, it is not surprising that Honneth $(2011,327)$, in his normative reconstruction of the economy in Freedom's Right, is concerned with the question of which institutional mechanisms and forms of socialization contribute to such a consciousness of social cooperation and solidarity. This brings us to the method of 'normative functionalism'. 


\subsection{Discursive Mechanisms and Legal Reforms}

The method of normative functionalism finds its origin in the 'tradition of moral economics' - consisting of Hegel, Durkheim, Parsons and Polanyi which Honneth tries to rehabilitate in Freedom's Right. This tradition emphasizes the importance of normative social integration in the economy, and argues that the market economy can only properly function and reproduce itself when it is embedded in reciprocal moral norms that obligate us to act in a fair and just manner, such as Durkheim's notion of the 'precontractual elements of the contract.'

However, as Honneth admits, it is rather unclear how we should understand these functionalist claims, since there have been many historical periods, for example the $19^{\text {th }}$ century, when the economy expanded and reproduced itself perfectly without any of these moral norms being realized. Honneth (2011, 331ff) therefore proposes to re-describe the approach of Hegel and Durkheim as normative functionalism, which means that they analyze the economy not by looking at how the economy actually functions and reproduces itself, but only by focusing on the normative conditions for the economy to reproduce itself in such a way that it can be understood by all participants as a legitimate sphere of social freedom.

What Honneth $(2011,349)$ finds especially interesting about Hegel and Durkheim is that they analyzed the institutional mechanisms that can foster such an understanding of the economy as a sphere of social freedom. Honneth $(2011,360)$ identifies two of those, namely discursive mechanisms and legal reforms. ${ }^{14}$ Both Hegel and Durkheim emphasized the importance of intermediate institutions such as corporations and professional groups, because these are crucial for integrating individuals in such a way in the economy that they learn to articulate their individual interests within a framework of cooperative responsibilities. Within these discursive mechanisms, individuals learn to take the perspective of others while articulating their own interests, and in this way learn to understand the market sphere as a cooperative sphere of social freedom. ${ }^{15}$ Honneth speaks here of the normative plasticity of interests, which means that the economic interests of individuals are dependent on the way in which individuals are integrated in the economy and the way in which they learn how to articulate their interests, either monologically or through cooperative discursive mechanisms (Honneth 2011, 350; 2013b, 353, 360). ${ }^{16}$

It was Durkheim who - besides emphasizing the importance of discursive mechanisms - also pointed to the importance of legal reforms for realizing equal and fair chances within the market sphere, and thus for increasing the number of people that can successfully integrate into the 
economy (Honneth 2011, 351ff). But Durkheim was at the same time aware that the emergence of social rights also had a negative effect, because the subjective character of these rights weakened the cooperative bonds, and forced individuals to understand and articulate their interests monologically. In this way, by making the conditions in the market sphere more equal, subjective rights have contributed to an understanding of the market as a just and fair cooperative project, but at the same time have undermined the flourishing of discursive mechanisms (Honneth 2011, 426-429).

One can recognize in discursive mechanisms and legal reforms the two institutional mechanisms that contribute to the realization of the two context-transcending principles of individualization and social inclusion that were discussed earlier. Discursive mechanisms stimulate the recognition of individual qualities within a cooperative whole, whereas legal reforms can increase the level of social inclusion. It is not surprising, therefore, that Honneth takes these two institutional mechanisms - which together determine the moral quality of social integration in the economy - as his guide in his normative reconstruction of the consumer market and the labor market. ${ }^{17}$

Besides analysing which institutional mechanisms contribute to the understanding of the economy as a sphere of social cooperation, Honneth has also tried in his article 'Labor and recognition: a redefinition' (Honneth 2010a) to articulate the reciprocal norms that can be found in the work of Hegel and Durkheim, and that should be in place in the labor market in order for participants to understand it as a sphere of social freedom. In Hegel he finds two of these norms, namely the obligation to work for one's living by satisfying others' needs, and to develop abilities and talents in such a way that they can contribute to society; and the opportunity to do reasonably paid work that has a certain degree of complexity, and in which certain skills can be demonstrated, so that the work can be understood and recognized as a worthy contribution to society (ibid., 89-90). Honneth adds - drawing on Durkheim - that the working activity should have a certain transparency, so that the individual can understand how his work meaningfully relates to the cooperative whole (ibid., 98).

This first group of norms implies that someone who is willing to work and make a contribution to society can make a justified claim to the availability of paid work that has a certain complexity and which can support a decent living (ibid., 94). The realization of these norms presupposes, however, that there are already discursive mechanisms in place that foster the reciprocal adjustment of economic interests in order to make them complementary.

Honneth finds another moral norm in Durkheim, namely that the 
exchange of services takes place under just and fair conditions, especially concerning equal chances. When the inequality between different classes in society exceeds a certain threshold, the understanding of the market as a sphere of social freedom becomes impossible, and therefore relative equality is a precondition for a consciousness of social cooperation. The institutional mechanisms for achieving this are legal reforms.

Honneth's conclusion in Freedom's Right is that the current dominant understanding of the market as a sphere of individual freedom, and not of social freedom, ${ }^{18}$ is largely the result of the disappearance of discursive mechanisms and the subjective character of social rights. Because individuals are not socially integrated in such a way that they can understand the economy as a cooperative sphere of social freedom, the reciprocal norms that are a precondition for the economy to be understood by all participants as legitimate cannot be realized.

Coming to the end of our reconstruction, we can conclude that Honneth's normative approach to the economy revolves around the moral quality of social integration (Fraser/Honneth 2003, 219). By pointing to the normative plasticity of economic interests, by analysing the institutional mechanisms that can improve the moral quality of social integration, and by articulating the underlying moral norms that should be in place for everybody to understand the economy as a sphere of social freedom, Honneth contributes to a de-naturalization of the supposed 'objective logic' of the economy propagated in different ways by mainstream economics, orthodox Marxism, and sociologists informed by functional differentiation. In this way, Honneth wants to open up new possibilities for cooperation and solidarity in the economy, which can then lead to a revitalization of democratic citizenship. ${ }^{19}$

\section{Critical Remarks}

What the above reconstruction has shown, is that Honneth has moved between two opposites in the thirty years between the articles 'Labor and instrumental action' (1980) and 'Labor and recognition' (2010a). Whereas his early craftsman ideal was immanent but lacked rationality, his recent approach of normative functionalism is rational but lacks immanence - at least if one follows Honneth's own assessment that there is hardly any collective, higher-level protest nowadays against the violation of the moral norms that he identifies as being necessary for the economy to be understood by all participants as legitimate. ${ }^{20}$

In this way, although Honneth's development of a normative approach to the economy started as a critical reaction to Habermas, he ends 
up with an approach that is very similar to that of Habermas, and faces similar problems. Just as Habermas tried to articulate the moral norms underlying the life-world (i.e. the ideal speech conditions), Honneth articulates the moral norms underlying the economy. And just as Habermas - after being criticized that his approach is idealistic - started to talk about the underlying moral norms in the life-world as 'counterfactual presuppositions,' Honneth defends his normative functionalism by arguing that we should understand the moral norms underlying the economy as counterfactual. ${ }^{21}$ This means that even when these norms do not have a proper force in the actual historical development of capitalism, they have not lost their immanent legitimacy, because only when these norms are in place can all participants understand the market as legitimate. Therefore, when Honneth speaks of the 'embedded' market he does not mean that these moral norms are always factually at work in the market, but it means that the economy is always dependent on them for its moral legitimacy. ${ }^{22}$

One can question whether Honneth does not move too far away here from his own methodological demand that his approach should be immanent and should remain close to the everyday, first-person experiences of individuals. Honneth's plea for a return to Hegelian and Durkheimian forms of socialization and integration seems to find no resonance in actual society, and this is perhaps not only because of pathological developments, but also because there are genuinely emancipating aspects related to the new forms of individualism in our times. The problem seems to be that Honneth, in his justified criticism of the pathological, individualistic forms of selfrealization in the economy and in other spheres of society, has difficulties with conceptualizing the emancipating aspects.

This becomes clear, for example, when one looks at the place of the romantic ideal of authentic self-realization in Honneth's account. In Freedom's Right Honneth gives no central place to it and seems to agree with Hegel that this is a pathological idea of freedom whereby the particular and universal cannot be reconciled, and that it therefore should be subsumed under a general Sittlichkeit. However, one can ask whether there is not something in this romantic ideal of freedom that is genuinely emancipating and should be saved. This is the argument made by Juliane Rebentisch (2012) and Christoph Menke (1996), who both try to save romantic irony from Hegel's attempt to subsume it under a general Sittlichkeit. ${ }^{23}$ On the basis of their arguments, one could argue that Honneth leaves too little room for the possibility that there are other legitimate ways to understand individual freedom which have no clear place in Hegel's structure.

Perhaps the challenge for Honneth is therefore not to succumb to a nostalgic return to $19^{\text {th }}$ century solutions - a nostalgia that can also be found 
in a recent article where Honneth (2014b) pleas for a return to an organic conception of society - but to combine the insights of Hegel and Durkheim concerning our fundamental interdependency with insights concerning the new emancipating aspects of contemporary forms of individualism. ${ }^{24}$ In this way, his normative approach to the economy can perhaps better fulfil his own left-Hegelian standard of being both immanent and rational. ${ }^{25}$

Hans Arentshorst (hans.arentshorst@jyu.fi) is a doctoral researcher in Social and Political Philosophy at the University of Jyväskylä and at Utrecht University. His research focuses on the problem of solidarity in the work of Pierre Rosanvallon, Axel Honneth and Charles Taylor.

\section{Bibliography}

Beckert, J. (1997) Grenzen des Marktes: Die sozialen Grundlagen wirtschaftlicher Effizienz Frankfurt/M: Campus

Beckert, J. (2012) 'Die Sittlichkeit der Wirtschaft: Von Effizienz- und Differenzierungstheorien zu einer Theorie wirtschaftlicher Felder' Berliner Journal für Soziologie 22 (2)

Boltanski, L. \& Honneth, A. (2009) 'Soziologie der Kritik oder Kritische Theorie? Ein Gespräch mit Robin Celikates' in R. Jaeggi \& T. Wesche (eds.) Was ist Kritik? Frankfurt/M: Suhrkamp

Van den Brink, B., \& Owen, D. (eds.) (2007) Recognition and Power. Axel Honneth and the Tradition of Critical Social Theory Cambridge: Cambridge University Press

Celikates, R. (2009) Kritik als soziale Praxis Frankfurt/M: Campus

Claassen, R. (2014) 'Social Freedom and the Demands of Justice: A Study of Honneth's Das Recht der Freiheit' Constellations, 21

Dewey, J. (1994) The Public and its Problems Athens: Shallow Press

Fraser, N. \& Honneth, A. (2003) Umverteilung oder Anerkennung? Frankfurt/M: Suhrkamp 
Honneth, A. (1980) 'Arbeit und instrumentales Handeln. Kategoriale Probleme einer kritischen Gesellschaftstheorie' in A. Honneth \& U. Jaeggi (eds.) Arbeit, Handlung, Normativität Frankfurt/M: Suhrkamp

Honneth, A. (1986a) 'Diskursethik und implizites Gerechtigkeitskonzept. Eine Diskussionsbemerkung' in W. Kuhlmann (ed.) Moralität und Sittlichkeit: Das Problem Hegels und die Diskursethik Frankfurt/M: Suhrkamp

Honneth, A. (1986b) Kritik der Macht Frankfurt/M: Suhrkamp

Honneth, A. (1992) Kampf um Anerkennung Frankfurt/M: Suhrkamp

Honneth, A. (2000) ‘Demokratie als reflexive Kooperation. John Dewey und die Demokratietheorie der Gegenwart' in Das Andere der Gerechtigkeit Frankfurt/M: Suhrkamp

Honneth, A. (ed.) (2002) Befreiung aus der Mündigkeit: Paradoxien des gegenwärtigen Kapitalismus Frankfurt/M: Campus

Honneth, A. (2007a) 'Rekonstruktive Gesellschaftskritik unter genealogischem Vorbehalt' in Pathologien der Vernunft Frankfurt/M: Suhrkamp

Honneth, A. (2007b) 'Recognition as Ideology' in B. van den Brink and D. Owen (eds.) Recognition and Power. Axel Honneth and the Tradition of Critical Social Theory Cambridge: Cambridge University Press

Honneth, A. (2010a) 'Arbeit und Anerkennung. Versuch einer theoretischen Neubestimmung' in Das Ich im Wir Berlin: Suhrkamp

Honneth, A. \& Hartmann, M. (2010b) 'Paradoxien der kapitalistischen Modernisierung. Ein Untersuchungsprogramm' in Das Ich im Wir Berlin: Suhrkamp

Honneth, A. (2011) Das Recht der Freiheit Berlin: Suhrkamp

Honneth, A. (ed.) (2013a) Strukturwandel der Anerkennung: Paradoxien sozialer Integration in der Gegenwart Frankfurt/M: Campus 
Honneth, A. (2013b) 'Die Moral im 'Kapital': Versuch einer Korrektur der Marxschen Ökonomiekritik' in R. Jaeggi \& D. Loick (eds.) Nach Marx Berlin: Suhrkamp

Honneth, A. (2014a) 'Die Grenzen des 'Homo Oeconomicus'. Zum intellektuellen Vermächtnis Albert O. Hirschmans' in Vivisektionen eines Zeitalters Berlin: Suhrkamp

Honneth, A. (2014b) `Die Krankheiten der Gesellschaft. Annäherung an einen nahezu unmöglichen Begriff' WestEnd, 1

Iser, M. (2008) Empörung und Fortschritt. Grundlagen einer kritischen Theorie der Gesellschaft Frankfurt/M: Campus

Jaeggi, R. (2014) Kritik von Lebensformen Berlin: Suhrkamp

Marcelo, G. (2013) 'Recognition and Critical Theory Today: an Interview with Axel Honneth' Philosophy and Social Criticism, 39 (2)

Menke, C. (1996) Tragödie im Sittlichen. Gerechtigkeit und Freiheit nach Hegel Frankfurt/M: Suhrkamp

Menke, C. \& Rebentisch, J. (eds) (2011) Kreation und Depression: Freiheit im gegenwärtigen Kapitalismus Berlin: Kadmos

Petheridge, D. (ed.) (2011) Axel Honneth: Critical Essays Leiden: Brill

Rebentisch, J. (2012) Die Kunst der Freiheit. Zur Dialektik demokratischer Existenz Berlin: Suhrkamp

Rosanvallon, P. (2011) La société des égaux Paris: Seuil

Smith, N. H. \& Laitinen, A. (2009) ‘Taylor on Solidarity’ Thesis Eleven, 99

Smith, N. H. \& Deranty, J.-P. (eds.) (2012) New Philosophies of Labor: Work and the Social Bond Leiden: Brill

Stahl, T. (2013) Immanente Kritik: Elemente einer Theorie sozialer Praktiken Frankfurt/M Campus 


\section{Endnotes}

${ }^{1}$ For an account of the left-Hegelian method, see also Fraser/Honneth (2003, 274ff). For a more detailed account of Honneth's methodology - which is usually referred to as reconstructive or immanent criticism - see Honneth (2011, 14-31). See also Iser (2008), Celikates (2009), and Stahl (2013): Iser compares the different ways in which Habermas and Honneth have applied reconstructive criticism, Celikates compares Honneth's approach to critical methods in French sociology (Bourdieu and Boltanksi), and Stahl tries to articulate the social-ontological presuppositions of immanent criticism. For a comparable, but slightly different approach, see Jaeggi (2014), who contrasts Honneth's reconstructive, immanent criticism with her own approach which she calls 'negativistisch inspirierte transformativimmanente Kritik' (294) ('negativistically inspired transformative-immanent criticism').

${ }^{2}$ As Honneth writes elsewhere: 'Habermas [hat] der Tradition kritischer Gesellschaftstheorie insofern eine entscheidende Wendung gegeben, als er das emanzipatorische, transzendierende Potential von der Praxisform der Arbeit abgezogen und auf das Handlungsmuster der sprachlich vermittelten Interaktion übertragen hat.' (Fraser/Honneth 2003, 284). ('Habermas has given the tradition of critical social theory a decisive turn insofar as he has transferred the emancipatory, transcending potential from the practice of labor to the action model of linguistically mediated interaction.')

3 '[D]ie taylorisierte, sinnentleerte Industriearbeit [ist] immer von einem gegenläufigen Handlungsprozeß begeleitet, in dem die Arbeitssubjekte kooperativ die Kontrolle über ihre eigene Tätigkeit zurückzugewinnen versuchen; aller entfremdeten Arbeit wäre dann ein Moment praktischer Erinnerung daran eigentümlich, daß ihr ungerechtfertigte Herrschaft innewohnt.' (Honneth 1980, 225). ('Taylorised, meaningless, industrial labor is always accompanied by a reverse process, in which workers try cooperatively to regain control over their activity; all alienated labor is in this way characterized by a moment that practically reminds us that it is based on unjustified domination.')

${ }^{4}$ Looking back on his craftsman ideal, Honneth describes it as 'strong perfectionism' (Brink/Owen 2007, 360). Cf. Honneth (2010a, 84-88). For a recent rehabilitation of a critical approach that revolves around the quality of the working activity itself, see the articles in Smith/Deranty (2012). 
5 This connection of moral progress and recognition-relations rests on Honneth's idea that there is a certain 'Logik der Erweiterung von Anerkennungsbeziehungen' (Honneth 1992, 269-270) ('logic according to which recognition relationships are expanded'), or, as he explains it elsewhere, there is a 'Geltungsüberhang' ('validity surplus') within the different recognition orders (Fraser/Honneth 2003, 207, 219-220; Honneth 2010b, 224).

${ }^{6}$ 'George H. Mead hatte demgegenüber, ähnlich wie etwa zur gleichen Zeit Durkheim, die gesellschaftliche Arbeitsteilung als die gemeinschaftliche Zielsetzung begriffen, von der jene solidarisierende Kraft ausgehen soll, durch die von alle Subjekte sich als wertgeschätzt wissen können; sein Vorschlag mußte jedoch daran scheitern, daß die Organisation der sozialen Arbeitsteilung, erst recht aber die Bewertung der verschiedenen Arbeitsleistungen, ihrerseits wieder von ethischen Wertvorstellungen abhängig ist' (Honneth 1992, 286). ('Mead, on the other hand - like Durkheim, at about the same time - had conceived the social division of labor as the framework of collective goals that is supposed to give rise to solidarity-generating forces, through which all subjects could know themselves to be esteemed. His suggestion was destined to founder, however, on the fact that, if not the organization of the social division of labor, then most certainly the evaluation of the diverse occupational achievements depends, itself, on ethical values.')

${ }^{7}$ As Honneth explains: '[I]f social esteem is linked conceptually to the exchange of services, then this problem [of the need of a shared ethical horizon] will not necessarily arise, at least not directly. Wholly independent of the ethical aims that individual members of society might pursue, they must share an interest in securing the material conditions of their social existence. It is for this reason that in my debate with Nancy Fraser I detached solidarity from the recognition of 'individual particularities' and linked it to the performance of individual contributions in economic exchange.' In: Petherbridge $(2011,407)$.

8 One should keep in mind here that Honneth understands 'individualization' in the tradition of Hegel, Marx, Durkheim and Dewey in which one can only become an autonomous individual within society: this in opposition to both the liberal tradition in which individuals are understood as preceding political society (as in the social-contract-tradition), and the existentialist tradition (Kierkegaard, Heidegger, etc.) in which one has to resist the leveling tendencies of society in order to become an authentic 
individual.

${ }^{9}$ Of course, one can ask if the notion of 'individualization' can still serve as a context-transcending principle when the principle of achievement has become distorted by neoliberal discourses about self-realization in terms of entrepreneurship and self-responsibility. It seems that it has become impossible for the critical theorist to decide which developments in this context are emancipatory and which are ideological. (Cf. Honneth 2007b).

${ }^{10}$ Cf. Menke/Rebentisch (2011)

${ }^{11}$ As Honneth recently described the current 'pathological' situation: 'Die institutionalisierten Spären der wechselseitigen Anerkennung scheinen an ihren Rändern wie zugemauert und in ihrem Inneren jedes allgemeinen, achtungssichernden Prinzips beraubt; immer mehr Gesellschaftsmitglieder sind auf kompensatorische, nicht-öffentliche Wege des Erwerbs der Selbstachtung angewiesen, immer weniger können für ihre Bestrebungen und Verrichtungen eine intersubjektiv geteilte Anerkennung reklamieren.' (2013a, 38). ('The institutionalized spheres of reciprocal recognition appear to have been made impenetrable from the outside and robbed of any general principal for guaranteeing respect; more and more citizens have become dependent on compensatory, non-public ways of gaining self-respect, less and less of them can cash in intersubjective recognition for their work and achievements.')

${ }^{12}$ See also Dewey: 'We have had occasion to refer in passing to the distinction between democracy as a social idea and political democracy as a system of government. The two are, of course, connected. The idea remains barren and empty save as it is incarnated in human relationships.' (Dewey 1927, 143)

${ }^{13}$ Honneth stresses the interdependency of being 'der freie Marktteilnehmer,' 'die selbstbewußte, demokratische Staatsbürgerin' and 'das emanzipierte Familienmitglied' (2011, 616) ('free market participants, self-aware democratic citizens and emancipated family members')

${ }^{14}$ Honneth gives different names to these discursive mechanisms, such as 'Mechanismen der Bewußtseinsbildung' (349-350) ('mechanisms of consciousness-formation'), 'Mechanismen der Perspektivübernahme' (351) ('mechanisms of switching perspective') and 'Mechanismen der Verallgemeinerung von Interessen' (408) ('mechanisms for generalizing interests'). 
15 As Honneth says: 'je mehr derartige diskursive Mechanismen der Perspektivübernahme im Marktverkehr verankert sind, desto größer dürfte die Chance sein, ein kooperatives Bewußtsein sich ergänzender Verantwortlichkeiten wachzuhalten' (2011, 351). ('the more such discursive mechanisms become anchored in the market, the greater the chance to preserve a cooperative awareness of mutually supplemental responsibilities')

${ }^{16}$ Honneth's idea of the normative plasticity of economic interests is mainly influenced by economic sociology, such as Albert Hirschman's 'possibilism' (see Honneth 2013b, 359-360; 2014a) and the work of Jens Beckert (1997, 2012). In a recent article, Honneth $(2013 b, 353)$ follows William Sewell in connecting the normative plasticity of interests also to historical events, which can be seen as another sign that Honneth's philosophy is becoming more and more historical and sociological, disconnected from strong anthropological claims.

${ }_{17}$ The argument of Rutger Claassen (2014) that Honneth pretends to have no constructive moment in his normative reconstruction of the economy is therefore not accurate. Honneth uses his 'rational' principles of individualization (discursive mechanisms) and social inclusion (legal reforms) as his guidelines for reconstructing the economy (Honneth 2011, 360).

18 'Zum ersten Mal seit dem Ende des Zweiten Weltkriegs, ja vielleicht sogar seit den ersten Schritten zur Etablierung des Wohlfahrtsstaates, wäre wieder eine Deutung des kapitalistischen Marktes kulturell zur Vorherrschaft gelangt, nach der dieser nicht eine Sphäre sozialer, sondern rein individueller Freiheit bildet.' (Honneth 2011, 462). ('For the first time since the end of World War II, and maybe since the first steps toward the establishment of the welfare state, an interpretation of the capitalist market would have come to dominate according to which the market constitutes a sphere of individual rather than social freedom.')

${ }^{19}$ In this sense, one can indeed argue like Nicholas Smith and Arto Laitinen that Honneth is part of a tradition of philosophers who promote 'socioeconomic solidarity': 'We find versions of [this socio-economic solidarity] in Hegel, Marx, Durkheim, Mauss, and Dewey; prominent contemporary expounders of it include Axel Honneth and Christophe Dejours.... For each of these thinkers, the experience of interdependency and cooperation that arises in socio-economic contexts of action is at least as important a source of solidarity as shared identification with a political, cultural, or national 
community, and participation in a public sphere separated from the world of production and exchange.' (Smith/Laitinen 2009, 62)

${ }^{20}$ In an interview Honneth argues: '[W]hy is the crisis we're having today in western capitalist societies not leading to higher forms or higher degrees of social protest? ... If we compare this situation to the one we had 40 years ago, when the degree of politicization was very high, we are simply surprised by the degree of de-politicization we have now.' (Marcelo 2013, 212). Cf. Honneth (2010a, 99; 2011, 459ff)

${ }^{21}$ Honneth speaks of 'kontrafaktische Geltungsgrundlage' ('counterfactual basis of validity'; 2010a, 95) and 'kontrafaktische Unterstellungen' ('counterfactual assumptions'; 2010a, 96, 98).

22 ‘Hier von einer 'Einbettung' zu reden bedeutet also, das Funktionieren des kapitalistischen Arbeitsmarktes von normativen Bedingungen abhängig zu machen, die er selbst nicht zwangsläufig erfüllen können muß: Das Geschehen auf dem weitgehend undurchsichtigen Markt des Austauschs von Arbeit vollzieht sich unter der Voraussetzung von moralischen Normen, die auch dann in Geltung bleiben, wenn die historische Entwicklung gegen sie verstößt.' (Honneth 2010a: 95). ('To speak of embedding in this context means making the functioning of the capitalist labour market dependent on normative conditions that it itself cannot necessarily fulfil. Events in the mostly opaque labour market are founded on moral norms that remain valid even if they are violated by actual developments.')

23 Rebentisch defines romantic irony as a 'historisch-dynamisch zu denkenden Vermittlung von innerer Natur und sozialer Gestalt des Subjekts.' (2012: 131) (a 'historical-dynamical mediation between the inner nature and social form of the subject')

${ }^{24}$ An example of such an approach is perhaps Pierre Rosanvallon's attempt to provide a new foundation for equality based on the principles of singularity, reciprocity and communality. See Rosanvallon (2011: 351ff).

${ }^{25}$ I would like to thank the members of the research-group 'Pathologies of recognition,' especially Federica Gregoratto, for helpful suggestions, also Axel Honneth for his comments on an earlier version of this paper at the workshop 'Pathologies of recognition' in Helsinki, May 2014, and finally Alison Beale for proofreading. 